\title{
Labour analgesia: what are the (new) options?
}

Mark C. Norris MD

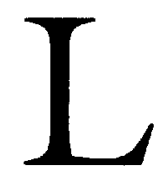

ABOUR is one of the most painful events that a woman will experience. Options for relieving this pain range from emotional support and psycho-prophylaxis ("natural" childbirth) to spinal and epidural analgesia. While the types of labour analgesia have changed little over the years, our understanding of their risks and benefits continues to evolve. The following is a highly selective review of some more recent information about the options available to a parturient who wants labour analgesia.

\section{Non-pharmacological pain relief}

Several studies have now shown that the continuous presence of a supportive, lay companion (Doula) has beneficial effects on the progress and outcome of labour. The Doula has several functions. She can provide emotional support, encouragement and reassurance to mother and partner. She can be a source of information and enhance communication with medical personnel. Lastly, she can provide physical support with massage and other forms of non-pharmacological pain relief. Randomised clinical trials have shown that the continuous presence of a supportive companion shortens labour by an average of $2.8 \mathrm{hr}$, halves the frequency of oxytocin use, forceps and Caesarean delivery. ${ }^{1}$ Continuous labour support also may significantly decrease the frequency of requests for epidural analgesia (Figure 1). ${ }^{2}$ Spurred by these results, Doula training and availability has become widespread in North America. A recent search of the World Wide Web found 338 links to Doula organisations.

\section{Systemic medications}

Despite providing little or no analgesia (Figure 2), ${ }^{3}$ systemic medications remain the most common approach to labour analgesia in the United States. ${ }^{4}$ Recent studies have suggested that giving systemic opioids by patientcontrolled pump (PCA) can enhance their efficacy. Podlas and Breland noted that patients were less drowsy and more satisfied when allowed to self medicate with nalbuphine ( $1 \mathrm{mg}, \mathrm{q}$ 6-10 $\mathrm{min}$ ) instead of receiving the drug by intermittent intravenous injection $(10-20 \mathrm{mg}$, q 4-6 hr). ${ }^{5}$ Another study reported that PCA nalbuphine ( $3 \mathrm{mg}$, q $10 \mathrm{~min}$ ) provided better labour analgesia than PCA meperidine $(15 \mathrm{mg}, \mathrm{q} 10 \mathrm{~min}) .{ }^{6} \mathrm{In}$ a case report, PCA fentanyl $(25 \mu \mathrm{g}, \mathrm{q} 10 \mathrm{~min}$ and a basal infusion of $25 \mu \mathrm{g} \cdot \mathrm{hr}^{-1}$ ) provided "effective analgesia" during labour in a woman with thrombocytopenia.? Recently, Sharma et al. used meperidine PCA (10-15 $\mathrm{mg}, \mathrm{q} 10 \mathrm{~min}$ ) in a study comparing systemic with

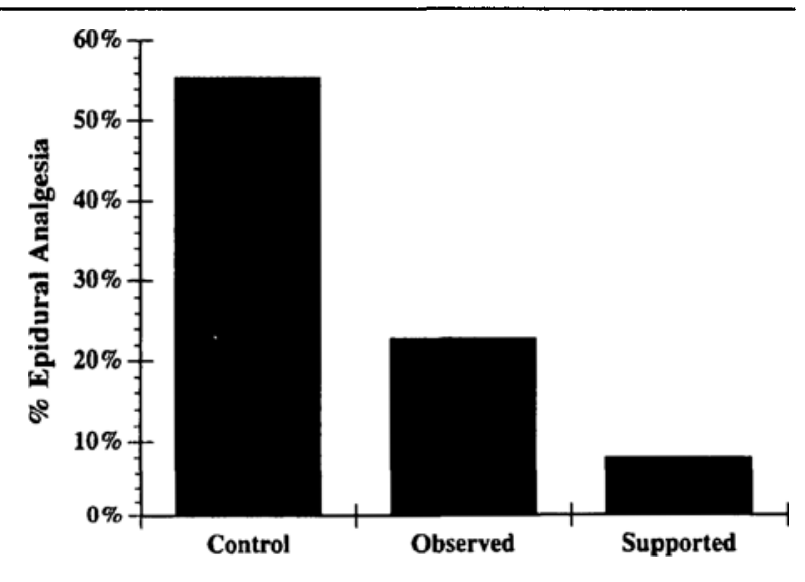

FIGURE 1 Impact of continuous labour support on the use of labour epidural analgesia. Data from ${ }^{2}$.

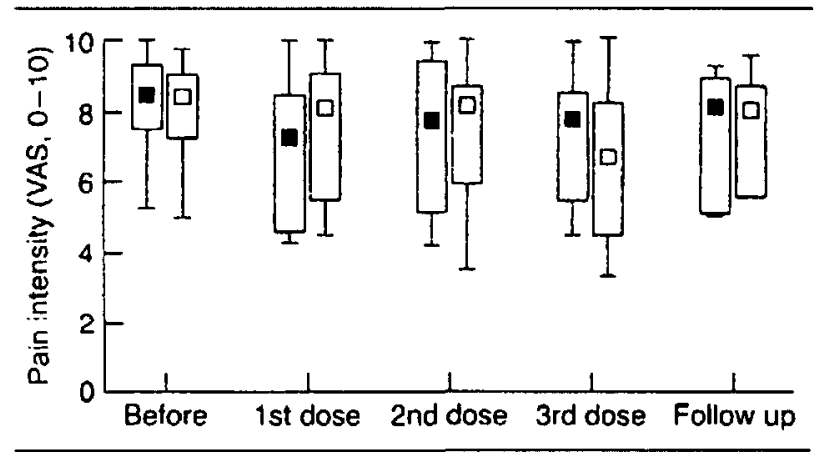

FIGURE 2 Pain intensity before and after repeated intravenous doses of morphine ( $0.05 \mathrm{mg} \cdot \mathrm{kg}^{-1}$ ) (closed square) or meperidine $\left(0.5 \mathrm{mg} \cdot \mathrm{kg}^{-1}\right)$ (open square) in labouring nulliparous women. Box and whisker plots show median, interquartile range and total range. Pain scores did not change with any dose. Reproduced from ${ }^{3}$ with permission of the publisher.

Departments of Anesthesiology and Obstetrics \& Gynecology, Washington University School of Medicine, 660 S. Euclid, Campus Box 8054, St. Louis, MO 63110. 


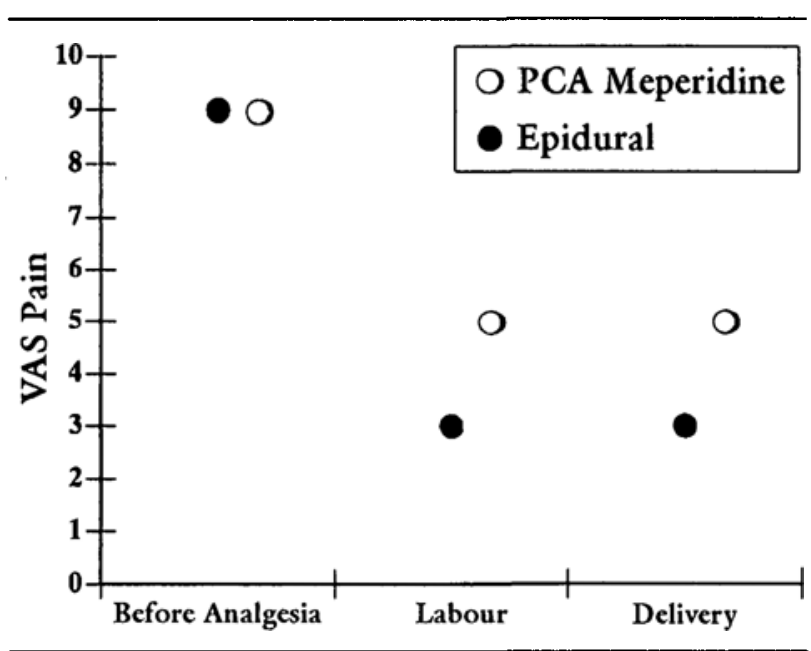

FIGURE 3 PCA meperidine $p s$ epidural bupivacaine for labour analgesia. Although PCA meperidine provided acceptable analgesia to most patients, women receiving epidural block had significantly less pain $(P<0.0001)$. Data from ${ }^{8}$.

epidural analgesia in labour (Figure 3 ). ${ }^{8}$ Although not yet reported, the new, ultrashort-acting synthetic opioid, remifentanil, may be ideal for this application. Remember, maternal respiratory arrest is a risk of opioids, regardless of the route of administration. ${ }^{9}$

Self administered nitrous oxide is a popular, noninvasive, technique for labour analgesia. Unfortunately, a double-blind, placebo-controlled, cross-over trial, failed to find any analgesic effect of intermittent inhalation of nitrous oxide $50 \%$ in oxygen when compared with compressed air (Figure 4). ${ }^{7}$ Despite the absence of analgesia, all patients could identify which gas was nitrous oxide, and many choose to continue using it after the study period. On the positive side, this study found that nitrous oxide inhalation did not increase the risk of maternal hypoxaemia.?

\section{Epidural analgesia}

Epidural analgesia remains the most effective way to relieve labour pain. In the United States, the use of epidural analgesia for labour increased considerably between 1981 and 1992, especially in larger hospitals (Figure 5) ${ }^{4}$ New options for the provision of labour epidural analgesia have arisen in several areas. There is a growing consensus that minimising maternal motor blockade can limit the adverse effects of epidural analgesia on the progress and outcome of labour. Options to achieve this end include: the new local anaesthetic ropivacaine; dilute local anaesthetic/opioid mixtures and intrathecal opioids, usually used as a part of a combined spinal epidural technique (CSE).

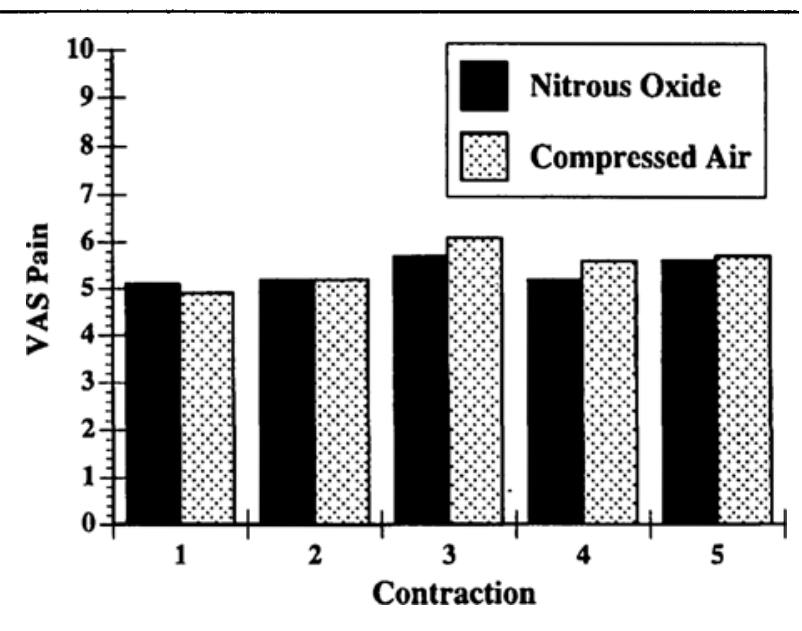

FIGURE 4 Pain scores for five consecutive contractions when breathing either nitrous oxide $50 \%$ in oxygen or compressed air. Nitrous oxide had no analgesic effect.

Data from ${ }^{7}$.

\section{Choice of local anaesthetic}

While many anaesthetists and obstetricians believe that minimising the amount of local anaesthetic used will limit the adverse effects of labour epidural analgesia on pregnancy outcome, there are surprisingly few data to support this notion. Decreasing the concentration of local anaesthetic does lower the risk of fetal head malposition. The fetal head does not turn to the occiput anterior position in about $4 \%$ of women who do not receive epidural analgesia. ${ }^{10}$ Techniques using intermittent injections of bupivacaine $(0.375 \%$ with $1: 200,000$ epinephrine) or lidocaine $(1.5 \%$ with 1:200,000 epinephrine) are associated with a high incidence of persistent malrotation $(16-26 \%) .10,11$ Using continuous infusions of dilute local anaestheticopioid mixtures (bupivacaine $0.0625 \%$ with $1 \mu \mathrm{g} \cdot \mathrm{ml}^{-1}$ fentanyl or $0.3 \mu \mathrm{g} \cdot \mathrm{ml}^{-1}$ sufentanil) seems to considerably decrease this risk (5-7\%). ${ }^{11,12}$

Dilute local anaesthetic/opioid mixtures also limit the effect of epidural analgesia on the length of the second stage of labour and the need for outlet forceps. Providing second stage analgesia with a continuous infusion of bupivacaine $0.0625 \%$ with fentanyl $0.0002 \%$ results in the same need for forceps as infusing normal saline..$^{13}$ Adding $10 \mu \mathrm{g}$ sufentanil to a $10 \mathrm{ml}$ bolus of bupivacaine $0.125 \%$ with $1: 800,000$ epinephrine decreases both the amount of bupivacaine needed to provide labour analgesia and the frequency of instrumented delivery. ${ }^{14}$

As yet, no data show that the concentration of local anaesthetic used is an important contributor to the "effect" of epidural analgesia on the need for Caesarean delivery. Indeed, two recent studies that failed to find 


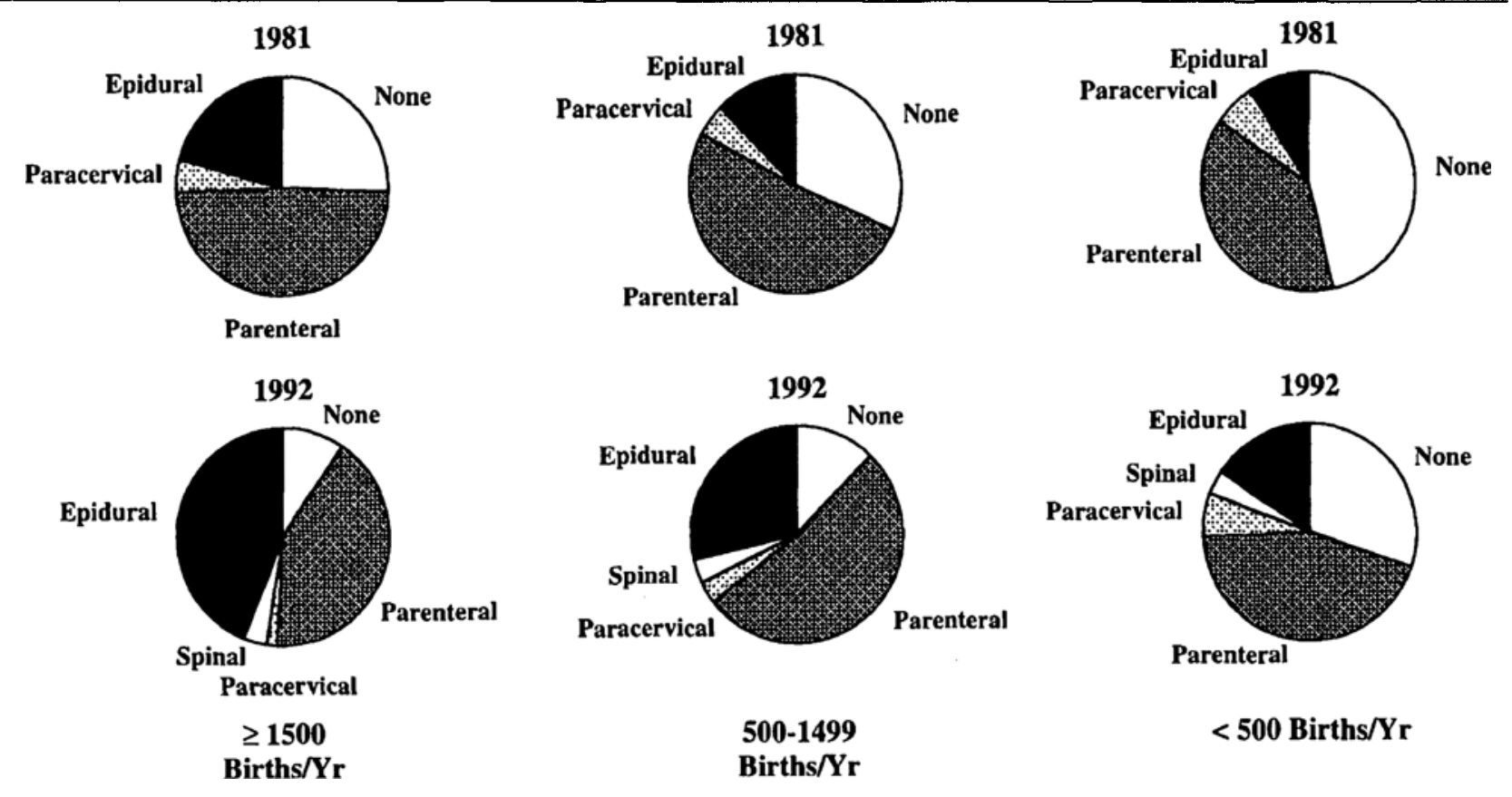

FIGURE 5 Methods of labour analgesia in the United States in 1981 (upper row) and 1992 (lower row). The columns are stratified by the number of deliveries per year. Data from ${ }^{4}$.

any increased risk of Caesarean delivery associated with labour epidural analgesia used continuous infusions of bupivacaine $0.125 \%$ with fentanyl. Despite the lack of effect on risk of Caesarean delivery, prolonged infusion of this mixture can cause significant maternal motor blockade, prolong the second stage of labour, increase the incidence of malpresentation and increase the frequency of instrumented delivery. ${ }^{12,15}$

Ropivacaine, in high concentrations, produces less motor block than bupivacaine. At lower concentrations, neither drug produces much motor blockade. ${ }^{16}$ As a sole agent, even ropivacaine $0.125 \%$ produces some motor weakness in most parturients. ${ }^{17}$ When used as part of a dilute local anaesthetic opioid mixture, it has proved to be less effective than an equal concentration of bupivacaine (Table).$^{18}$

Until recently, the exact composition of these dilute local anaesthetic/opioid mixtures has been empirically derived. Recent studies have systematically evaluated the interaction between local anaesthetics and opioids when used for labour epidural analgesia. Columb and colleagues have conducted an elegant series of studies that define the median effective local anaesthetic concentration (MLAC) in labouring women. The MLAC is defined as the concentration of local anaesthetic that, when given in a $20 \mathrm{ml}$ volume, will produce analgesia in $50 \%$ of women in the first stage of labour. ${ }^{19}$ Both fentanyl and sufentanil decrease the MLAC of epidural bupivacaine in a dose-dependent fashion (Figure 6). ${ }^{19,20}$ The optimal concentration of epidural fentanyl appears to be $3 \mu \mathrm{g} \cdot \mathrm{ml}^{-1}$. Larger doses increase the frequency of itching. ${ }^{19}$

\section{Combined spinal epidural analgesia}

Combined spinal epidural analgesia (CSE) using intrathecal opioids and an epidural infusion of a dilute local anaesthetic/opioid mixture is rapidly gaining popularity as a labour analgesia option. The proved advantages of this technique include rapid onset, ${ }^{21}$ and high maternal satisfaction. ${ }^{22}$ Most anaesthetists use the needle-throughneedle technique to provide CSE. Despite theoretical concerns about metallic particles, dural passage of the

TABLE Bupivacaine vs ropivacaine for labour analgesia

\begin{tabular}{llll}
\hline & Bupivacaine & Ropivacaine & $P$ \\
\hline VAS @ 8 min & 3.0 & 0.8 & $<0.05$ \\
VAS @ 10 min & 1.6 & 0 & $<0.05$ \\
VAS @ 14 min & 0.7 & 0.0 & NS \\
Patients with > 1 bolus dose & 6 & 0 & $<0.05$ \\
Patients with motor block & 0 & 0 & NS \\
\hline
\end{tabular}

Epidural catheters were inserted and then dosed with $45 \mathrm{mg}$ lidocaine $+15 \mu \mathrm{g}$ epinephrine followed by a $15 \mathrm{ml}$ bolus containing $20 \mathrm{mg}$ local anaesthetic $(0.13 \%)$ and $10 \mu \mathrm{g}$ sufentanil. Analgesia was maintained with a continuous infusion of $0.07 \%$ local anesthetic and $0.5 \mathrm{\mu g} \cdot \mathrm{ml}^{-1}$ sufentanil at $12 \mathrm{ml} \cdot \mathrm{hr}^{-1}$. Data from ${ }^{18}$. 


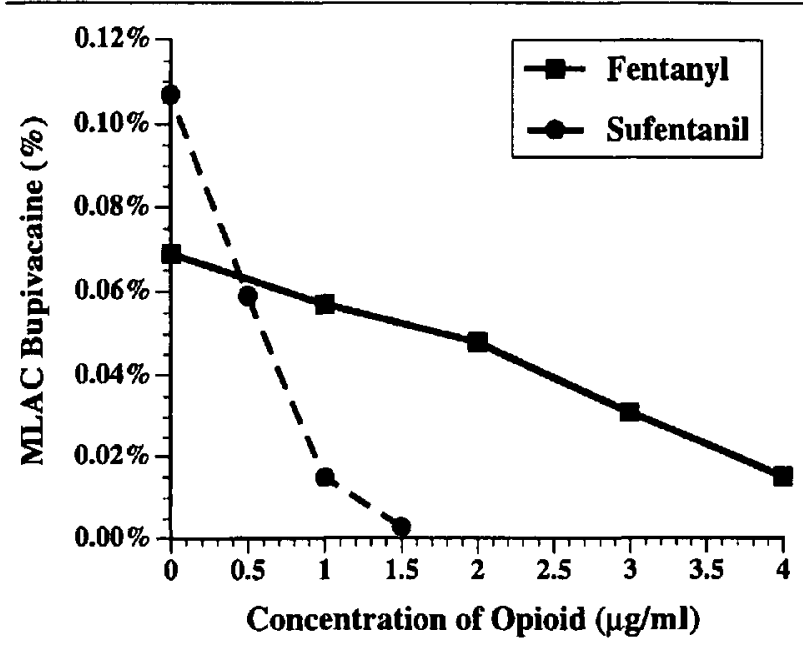

FIGURE 6 Effect of increasing doses of fentanyl or sufentanil on the median local anaesthetic concentration (MLAC) of bupivacaine. Labouring women received and epidural injection of $20 \mathrm{ml}$ bupivacaine/opioid mixture. Effective analgesia was defined as a pain score $\leq 10$ within 30 min. Both fentanyl and sufentanil produced significant, dose-dependent reductions in bupivacaine MLAC.

Data from 19,20

epidural catheter, meningitis and postdural puncture headache, the risks of the CSE technique are comparable to those of epidural anaesthesia. ${ }^{23}$ Facilitated spread of epidurally injected drug does occur with spinal injection. ${ }^{24}$ This effect appears to be related to enhanced diffusion of epidurally injected drug across the dural hole (Figure 7). ${ }^{26}$ In labouring women, epidural bupivacaine produces sensory block in one to two more dermatomes when injected after dural puncture than when used as a part of an epidural anaesthetic. ${ }^{13,24}$

Potentially more important than the risks of the needle-through-needle technique are the risks related to the intrathecal injection of opioids. Two concerns are especially pertinent: respiratory depression and fetal heart changes.

\section{Respiratory depression}

Intrathecal sufentanil has been associated with maternal respiratory depression and arrest in a variety of circumstances. The first reports of this complication occurred in women receiving large doses $(15 \mu \mathrm{g})$ or repeated injections of drug. ${ }^{26,27}$ Subsequent authors reported cases after $10 \mu \mathrm{g}$ sufentanil, either alone, or combined with $2.5 \mathrm{mg}$ bupivacaine ${ }^{28,29}$ In one case series, the risk of respiratory arrest after intrathecal sufentanil was approximately 1:5000. ${ }^{29}$ Intrathecal injection is a very effective way of delivering sufentanil to the brainstem. ${ }^{30}$ Elevated $\mathrm{P}_{\mathrm{ET}} \mathrm{CO}_{2}$ and depression of the ventilatory response to carbon dioxide occur commonly. ${ }^{31,32}$ Patients who have previously received systemic opioids may be at increased risk of this complication. ${ }^{29,33}$ All parturients who receive

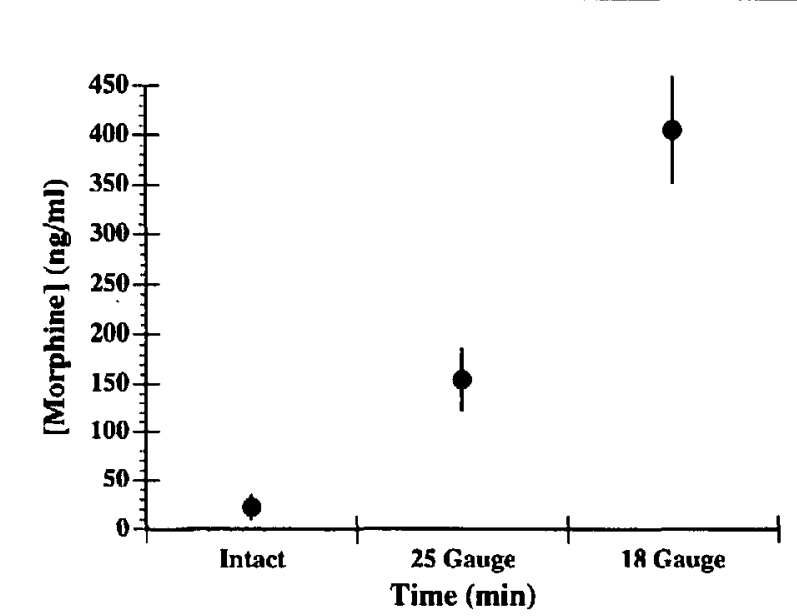

FIGURE 7 Mean \pm SD cerebrospinal fluid concentration of morphine measured at the cisterna magna six hours after lumbar epidural injection of $0.2 \mathrm{mg} \cdot \mathrm{kg}^{-1}$ morphine in sheep. In some animals, the lumbar aura was pierced with an 18 or 25 ga needle one hour before morphine injection.

Data from ${ }^{25}$.

intrathecal sufentanil should be monitored with pulse oximetry for at least one hour after injection.

\section{Fetal heart rate changes}

Depending on the definition, fetal bradycardia occurs in $3.9-23 \%$ of labouring women receiving intrathecal fentanyl or sufentanil. ${ }^{34-36}$ Some authors have suggested that the risk of this problem is greater after intrathecal than epidural labour analgesia. ${ }^{34}$ However, review of earlier literature shows that fetal bradycardia also follows induction of bupivacaine labour epidural analgesia $7.9-12.5 \%$ of the time. ${ }^{37}$ Two recent studies failed to find any differences between epidural and intrathecal labour analgesia in the frequency of fetal bradycardia (3.9-15.4\%) or "clinically significant fetal heart rate abnormalities" (22\%). ${ }^{35,36}$ Uterine hypertonus has been implicated as the cause of fetal bradycardia after both epidural and intrathecal labour analgesia. ${ }^{35,37,38}$ These fetal bradycardias usually resolve without fetal compromise or the need for surgical intervention.

\section{Site of action}

Some drugs (i.e., local anaesthetics) have a clearly segmental, spinal site of action after intrathecal injection. Other drugs (e.g., opioids, neostigmine) spread rapidly throughout the cerebrospinal fluid and reach supraspinal as well as spinal sites of action. We have long assumed that intrathecal opioids such as fentanyl and sufentanil produce labour analgesia at a spinal site while occasionally ascending to the brainstem to induce side 


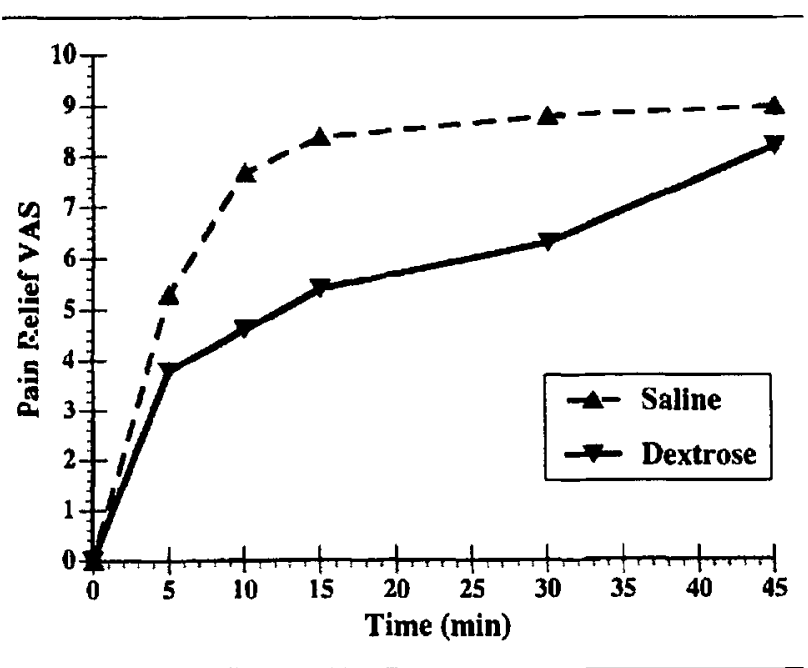

FIGURE 8 Pain relief visual analog scores (VAS) in labouring women who received and intrathecal injection of sufentanil $10 \mu \mathrm{g}$ diluted with either saline or dextrose. Hyperbaric sufentanil produces less analgesia than isobaric drug.

Data from ${ }^{30}$.

effects like nausea, somnolence and respiratory depression. A recent study, however, suggests that some of the analgesia produced by intrathecal sufentanil also comes from an effect at supraspinal sites. ${ }^{30}$ Ferouz et al. compared the efficacy and side effects of isobaric and hyperbaric sufentanil in labouring women. As expected, isobaric $10 \mu \mathrm{g}$ sufentanil rapidly produced both labour analgesia and itching. But, hyperbaric sufentanil, which the authors had hoped would provide spinally mediated analgesia without supraspinally mediated side effects, produced only limited analgesia (Figure 8). Presumably, hyperbaric sufentanil spread to the lower thoracic spinal cord, but not to the brainstem. These results suggest that analgesia after intrathecal sufentanil results from actions at both spinal and supraspinal sites. This theory is supported by animal studies that show synergism between spinal and supraspinal opioids. ${ }^{39}$ Clinically, this finding means that supraspinal side effects, such as respiratory depression, may be inseparable from the analgesic action of intrathecally injected drugs.

\section{Conclusion}

While there are no "new" options for relieving labour pain, our understanding of the currently available techniques continues to evolve. We are fortunate that we currently have the ability to relieve labour pain safely. Time and careful clinical and laboratory studies will improve our understanding of the strengths and limitations of the currently available approaches to labour analgesia and allow us to refine and improve continuously the care we can offer these women.

\section{References}

1 Zhang J, Bernasko JW, Leybovich E, Fabs $M$, Hatch $M C$. Continuous labour support from labour attendant for primiparous women: a metaanalysis. Obstet Gynecol 1996; 88: 739-44.

2 Kennell J, Klaus M, McGrath S, Robertson S, Hinkley C. Continous emotional support during labour in a US hospital. A randomized controlled trial. JAMA 1991; 265: 2197-201.

3 Olofason C, Ekblom A, Ekman-Orderberg G, Hjelm A, Irestedt $L$. Lack of analgesic effect of systemically administered morphine or pethidine in labour pain. Br J Obstet Gynaecol 1996; 103: 968-72.

4 Hawkins JL, Gibbs CP, Orleans M, Martin-Salvaj G, Beaty $B$. Obstetric anesthesia workforce survey: 1981 versus 1992. (Abstract) Anesthesiology 1997; 87: $135-43$.

5 Podlas J, Breland BD. Patient-controlled analgesia with nalbuphine during labour. Obstet Gynecol 1987; 70: 202-4.

6 Frank M, McAteer EJ, Cattermole R, Loughnan B, Stafford $L B$, Hitchcock $A M$. Nalbuphine for obstetric analgesia. A comparison of nalbuphine with pethidine for pain relief in labour when adminsitered by patient-controlled analgesia (PCA). Anaesthesia 1987; 42: 697-703.

7 Carstoniu J, Levytam S, Norman P, Daley D, Katz J, Sandler $A N$. Nitrous oxide in early labour. Safety and analgesic efficacy assessed by a double-blind, placebocontrolled study. Anesthesiology 1994; 80: 30-5.

8 Sharma SK, Sidawi JE, Ramin SM, Lucas MJ, Leveno KJ, Cunningham FG. Cesarean delivery. A randomized trial of epidural versus patient controlled meperidine analgesia during labour. Anesthesiology 1997; 87: 486-94.

9 Garner KG, Smith CV, Rayburn WF. Maternal respiratory arrest associated with intravenous fentanyl use during labour. A case report. J Reprod Med 1994; 39 : 818-20.

10 Parker $R K$. Influence of labour epidural management on outome in obstetrics. (Abstract) Reg Anesth 1992; 17: $\$ 31$.

11 Naulty JS, March MG, Leavitt KL, Smith R, Urso PR. Effect of changes in labour analgesic practice on labour outcome. Anesthesiology 1992; 77: A979.

12 Stoddart AP, Nicholson KEA, Popham PA. Low dose bupivacaine/fentanyl epidural infusions in labour and mode of delivery. Anaesthesia 1994; 49: 1087-90.

13 Chestnut DH, Laszewski LJ, Pollack KL, Bates JN, Manago NK, Choi WW. Continuous epidural infusion of $0.0625 \%$ bupivacaine- $0.0002 \%$ fentanyl during the second stage of labour. Anesthesiology 1990; 72: 613-8.

14 Vertommen JD, Vandermeulen E, Van Aken $H$, et al. The effects of the addition of sufentanil to $0.125 \%$ bupivacaine on the quality of analgesia during labour 
and on the incidence of instrumental deliveries. Anesthesiology 1991; 74: 809-14.

15 Chestnut DH, Vandewalker GE, Owen CL, Bates JN, Choi $W W$. The influence of continuous epidural bupivacaine analgesia on the second stage of labour and method of delivery in nulliparous women. Anesthesiology 1987; 66: 774-80.

16 Reynolds $F$. Does the left hand know what the right hand is doing? An appaisal of single enantiomer local anaesthetics. Int J Obstet Anesth 1997; 6257: 269.

17 Owen $M D, D^{\prime}$ Angelo $R$, Gerancher JC, et al. 0.125\% ropivacaine is not superior to $0.125 \%$ bupivacaine for labour analgesia utilizing PCEA. Anesthesiology 1997; 87: A907.

18 Peres da Silva E, Abboud TK, Lee J. Comparison of $0.07 \%$ ropivacaine plus sulentanil and $0.07 \%$ bupivacaine plus suLentanil for epidural anesthesia during labour and delivery. Anesthesiology 1997; 87: A882.

19 Lyons G, Columb M, Hawthorne L, Dresner $M$. Extradural pain relief in labour: bupivacaine sparing by extradural fentanyl is dose dependent.

Br J Anaesth 1997; 78: 493-7.

20 Polley LS, Columb MO, Wagner DS, Naughton NN, Youn PY, Thessen CC. Dose dependent reduction of the minimum local analgesic concentration (MLAC) of bupivacaine by sulentanil for epidural analgesia in labour. Anesthesiology 1998; (in press).

21 D'Angelo R, Anderson MT, Philip J, Eisenach JC. Intrathecal sufentanil compared to epidural bupivacaine for labour analgesia. Anesthesiology 1994; 80: 1209-15.

22 Collis RE, Davies DWL, Aveling W. Randomised comparison of combined spinal-epidural and standard epidural analgesia in labour. Lancet $1995 ; 345$ : 1413-6.

23 Norris MC, Grieco WM, Borkowski $M$, et al. Complications of labour analgesia: epidural versus combined spinal epidural techniques. Anesth Analg 1994; 79: 529-37.

24 Leighton BL, Arkoosh VA, Huffnagle S, Huffnagle $H J$, Kinsella SM, Norris MC. The dermatomal spread of epidural bupivacaine with and without prior intrathecal sutentanil. Anesth Analg 1996; 83: 526-9.

25 Swenson JD, Wisniewski $M$, McJames $S$, Asbburn MA, Pace NL. The effect of prior aural puncture on cisternal cerebrospinal fluid morphine concentrations in sheep after administration of lumbar epidural morphine. Anesth Analg 1996; 83: 523-5.

26 Hays $R L$, Palmer CM. Respiratory depression after intrathecal sufentanil during labour. Anesthesiology 1994; 81: 511-2.

28 Greenhalgh $C A$. Respiratory arrest in a parturient following intrathecal injection of sutentanil and bupivacaine. Anaesthesia 1996; 51: 173-5.
29 Ferouz F, Norris MC, Leighton BL. Respiratory arrest after intrathecal sutentanil. Anesth Analg 1997; 85: 1088-90.

30 Ferouz $F$, Norris $M C$, Arkoosh VA, Leighton $B L$, Boxer $L M$, Corba $R J$. Baricity, needle direction, and intrathecal sufentanil labour analgesia. Anesthesiology 1997; 86: 592-8.

31 Lu JK, Schafer PG, Gardner TL, et al. The doseresponse pharmacology of intrathecal sutentanil in female volunteers. (Abstract) Anesth Analg 1997; 85: 372-8.

32 Norris $M C$, Ryan C, Fogel S, Holtmann B. Intrathecal sufentanil increases end-tidal $\mathrm{C} 02$ in labouring women. Anesthesiology 1997; 87: A885.

33 Jaffee JB, Drease GE, Kelly T, Newman LM. Severe respiratory depression in the obstetric patient after intrathecal meperidine or sufentanil. Int J Obstet Anesth 1997; 6: 182-4.

34 Clarke VT, Smiley RM, Finster $M$. Uterine hyperactivity after intrathecal injection of fentanyl for analgesia during labour: a cause of fetal bradycardia? Anesthesiology 1994; 81: 1083.

35 Eberle RL, Norris MC, Mallozzi Eberle A, Naulty JS, Arkoosh VA. The effect of maternal position on fetal heart rate during epidural or intrathecal analgesia for labour. Anesthesiology 1995; 83: A944.

36 Nielsen PE, Erickson JR, Abouleish EI, Perriatt S, Sheppard $C$. Fetal heart rate changes after intrathecal sufentanil or epidural bupivacaine for labour analgesia: incidence and clinical signficance. Anesth Analg 1996; 83: 742-6.

37 Steiger RM, Nagoette MP. Effect of uterine contractility and maternal hypotension on prolonged decelerations after bupivacaine epidural anesthesia. Am J Obstet Gynecol 1990; 163: 808-12.

38 Friedlander JD, Fox $H E$, Cain $C F$, Dominquez $C L$, Smiley $R M$. Fetal bradycardia and uterine hyperactivity following subarachnoid administration of fentanyl during labour. Reg Anesth 1997; 22: 378-81.

39 Roerig SC, Fujimoto JM. Multiplicative interaction between intrathecally and intracerebroventricularly administered $\mathrm{mu}$; opioid agonists but limited interactions between delta and kappa agonists for antinociception in mice. J Pharmacol Exp Ther 1989; 249: 762-8. 


\section{Analgésie durant le travail: quelles sont les nouvelles options?}

Mark C. Norris, MD

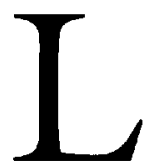

E travail est l'une des expériences les plus douloureuses expérimentées par la femme. Les modalités de soulagement de cette douleur s'étendent du support émotif et de la pshycho-prophylaxie (accouchement "naturel») à l'analgésie péridurale et rachidienne. Bien que les modalités analgésiques pour le travail aient peu changé au cours des ans, notre compréhension de leurs risques et bénéfices continue à progresser. Je vous propose ici une revue très sélective de l'information récente concernant les options disponibles pour la parturiente qui désire une analgésie durant le travail.

\section{Soulagement non pharmacologique de la douleur}

Plusieurs études ont montré que la présence continue d'un accompagnant laïque, apportant son soutien (DOULA) a des effets bénéfiques sur le déroulement du travail et sa conclusion. La DOULA a plusieurs fonctions. Elle peut apporter un support émotif, de l'encouragement et de la réassurance à la mère et à son partenaire. Elle peut être une source d'information et améliorer la communication avec le personnel médical. Enfin, elle peut apporter un support physique au moyen de massages et d'autres formes de soulagement non pharmacologique. Des études cliniques aléatoires ont montré que la présence continue d'un accompagnant apportant son soutien raccourcit le travail de 2,8 heures en moyenne, diminue de moitié la fréquence d'utilisation de l'oxytocine, d'utilisation de forceps et de césarienne ${ }^{1}$. Un appui constant durant le travail peut diminuer de façon significative la fréquence des demandes d'analgésie péridurale (Figure 1$)^{2}$. Suite à ces résultats, la formation DOULA et sa disponibilité se sont généralisées en Amérique du Nord. Une enquête récente sur le World Wide Web a permis d'identifier 338 connections à des organisations DOULA.

\section{Médications systémiques}

Même si elles apportent peu ou pas d'analgésie (Figure 2$)^{3}$, les médications systémiques demeurent l'approche la plus utilisée pour l'analgésie durant le travail aux Etats-Unis ${ }^{4}$. Des études récentes suggèrent que l'administration des opiacés par voie systémique en utilisant des pompes ACP améliore leur efficacité. Podlas et Breland notent que les patientes sont moins somnolentes et plus satisfaites quand on leur permet l'autoadministration de nalbuphine (1 $\mathrm{mg}$ q 6-10 min) plutôt que de recevoir la médication par doses intraveineuses intermittentes $(10-20 \mathrm{mg} \mathrm{q} \mathrm{4-6} \mathrm{h})^{5}$. Une autre étude rapporte que l'ACP avec nalbuphine (3 $\mathrm{mg} \mathrm{q} 10 \mathrm{~min}$ ) procure une meilleure analgésie durant le travail que l'ACP avec mépéridine $(15 \mathrm{mg} \mathrm{q}$

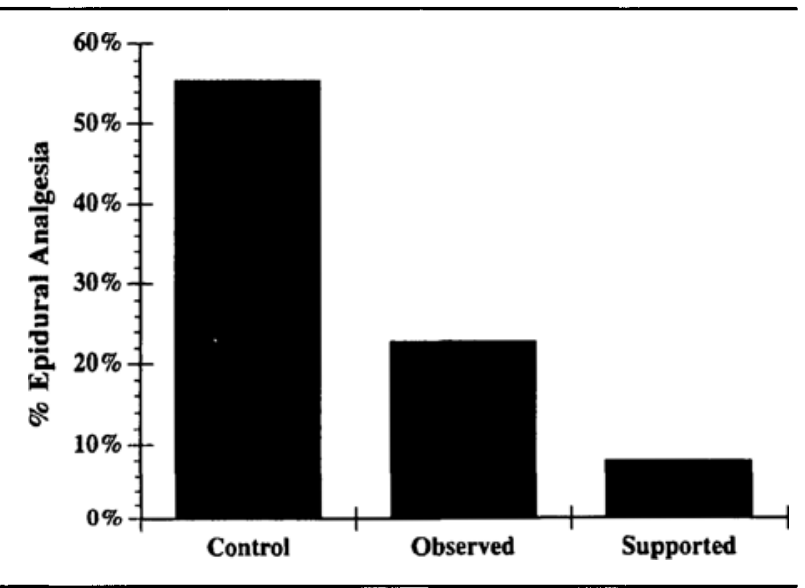

FIGURE 1: Impact de l'assistance continue durant le travail sur l'utilisation d'analgésie péridurale durant le travail. Réf. 2.

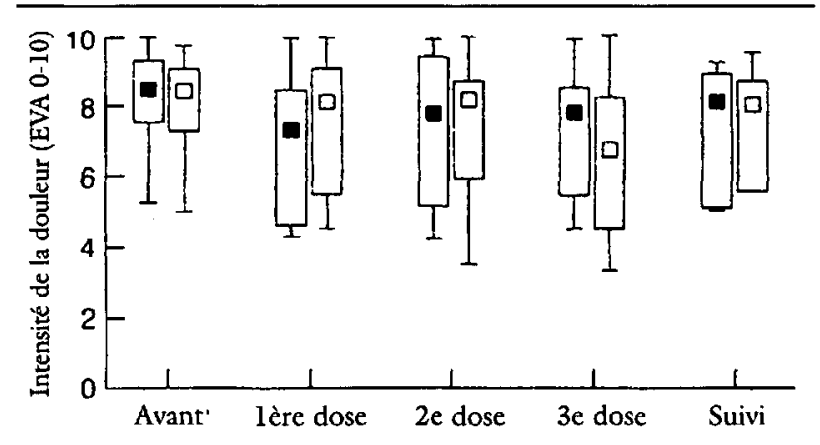

FIGURE 2 : Intensité de la douleur avant et après des doses iv répétées de morphine à $0,05 \mathrm{mg} \cdot \mathrm{kg}^{-1}$ (carrés foncés) ou de mépéridine à $0,5 \mathrm{mg} \cdot \mathrm{kg}^{-1}$ (carrés clairs) chez des nullipares en travail. Le graphique indique la médiane, l'intervalle entre les quartiles et l'intervalle total. L'évaluarion de la douleur est demeurée inchangée à toutes les doses. Réf. 3. Reproduit avec autorisation de l'éditeur. 


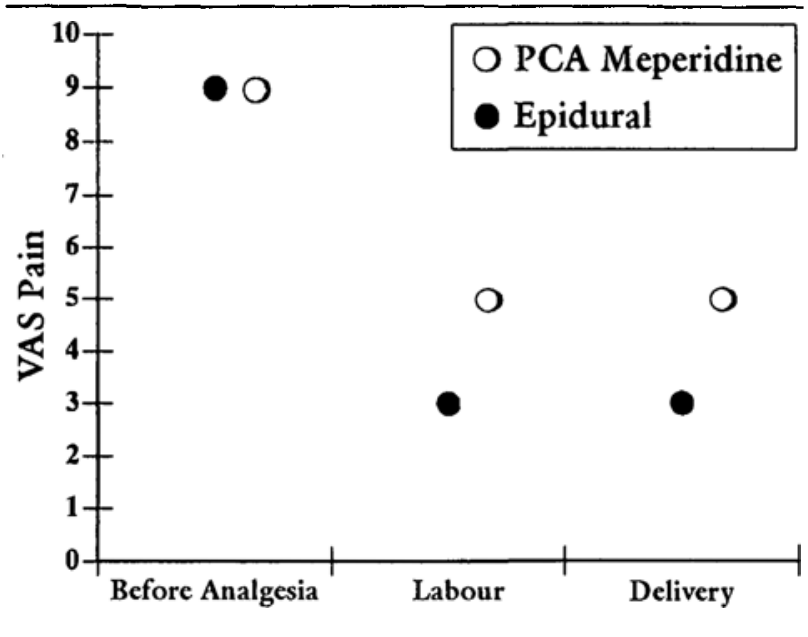

FIGURE 3 : ACP avec mépéridine vs bupivacaïne péridurale pour l'analgésie durant le travail. Même si la mépéridine a apporté une analgésie acceptable à la majorité des patientes, les femmes sous péridurale avaient moins de douleur de façon significative $(P<0,0001)$. Réf. 8 .
$10 \mathrm{~min})^{6}$. Dans un rapport à propos d'un cas, l'ACP avec fentanyl ( $25 \mathrm{~g} \mathrm{q} 10 \mathrm{~min}$ avec perfusion de $25 \mathrm{~g}$ $h^{-1}$ ) a fourni «une analgésie efficace» durant le travail à une parturiente porteuse de thrombocytopénie ${ }^{7}$. Récemment, Sharma et al. ont utilisé l'ACP avec mépéridine (10-15 $\mathrm{mg} \mathrm{q} 10 \mathrm{~min}$ ) dans une étude comparant l'analgésie systémique à l'analgésie épidurale durant le travail (Figure 3$)^{8}$. Bien que n'ayant pas encore fait l'objet d'articles, un nouvel opiacé synthétique à action ultracourte, le rémifentanil, pourrait être l'agent idéal pour ce type d'utilisation. Se souvenir que l'arrêt respiratoire chez la mère est un risque des opiacés, quelle que soit la voie d'administration?.

L'autoadministration de protoxyde d'azote est une technique populaire non invasive pour l'analgésie durant le travail. Malheureusement, des études à double insu, contre placebo, et selon le mode essai croisé, n'ont pas permis de démontrer d'effet analgésique lorsque l'inhalation intermittente de protoxyde à $50 \%$ dans l'oxygène est comparée à l'air comprimé (Figure 4$)^{7}$. Malgré l'absence d'analgésie, toutes les parturientes pouvaient identifier le protoxyde d'azote et plusieurs ont choisi de continuer à l'utiliser à la fin de la période de recherche. Du côté positif, cette étude a démontré que le protoxyde n'augmentait pas le risque d'hypoxémie maternelle?

\section{Analgésie périduale}

L'analgésie péridurale demeure le mode de soulagement de la douleur le plus efficace durant le travail. Aux ÉtatsUnis, l'utilisation de l'analgésie péridurale pour le travail

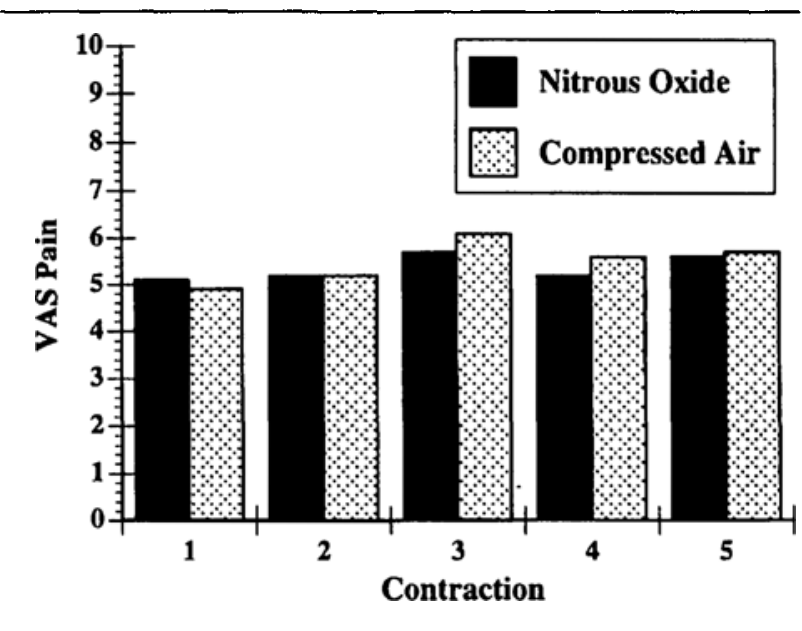

FIGURE 4 : Évaluation de la douleur pour cinq contractions consécutives sous $\mathrm{N} 2 \mathrm{O} / \mathrm{O} 250 \%$ ou air comprime. Le N2O n'a pas d'effet analgésique. Réf. 7.

a augmenté considérablement entre 1981 et 1992 , spécialement dans les hôpitaux majeurs (Figure 5$)^{4}$. De nouvelles options dans la façon de réaliser la péridurale pour le travail se sont développées. Il existe un sentiment généralisé que le fait de minimiser le bloc moteur maternel peut limiter les effets indésirables de l'analgésie péridurale sur la progression du travail et son aboutissement. Les options pour arriver à ce but sont les suivantes : un nouvel anesthésique local, la ropivacaïne; les mélanges d'anesthésique local dilué et d'opiacé et les opiacés intrathécaux, en général utilisés dans le cadre d'une technique péridurale-rachidienne combinée.

\section{Choix de l'anesthésique local}

Alors que plusieurs anesthésistes et obstétriciens croient que le fait de garder au minimum la quantité d'anesthésique local utilisé limitera les effets néfastes de l'analgésie péridurale durant le travail sur l'aboutissement de la grossesse, il y a de façon étonnante peu de données pour appuyer cette notion. Le fait de diminuer la concentration de l'anesthésique local diminue le risque de malposition de le tête foetale. La rotation de la tête foetale en position occiput antérieure ne se fait pas chez environ $4 \%$ des femmes ne recevant pas d'analgésie péridurale ${ }^{10}$. Les techniques utilisant des injections intermittentes de bupivacaïne, $0,375 \%$ avec adrénaline $1: 200,000$, ou de lidocaïne, $1,5 \%$ avec adrénaline $1: 200,000$, sont associées à une incidence élevée de malrotation persistante $(16-26 \%)^{10,11}$. L'utilisation de perfusions continues de mélanges d'anesthésique local dilué et d'opiacés (bupivacaïne $0,0625 \%$ avec fentanyl $\mathrm{l} \mathrm{g} \cdot \mathrm{ml}^{-1}$ ou sufentanil 


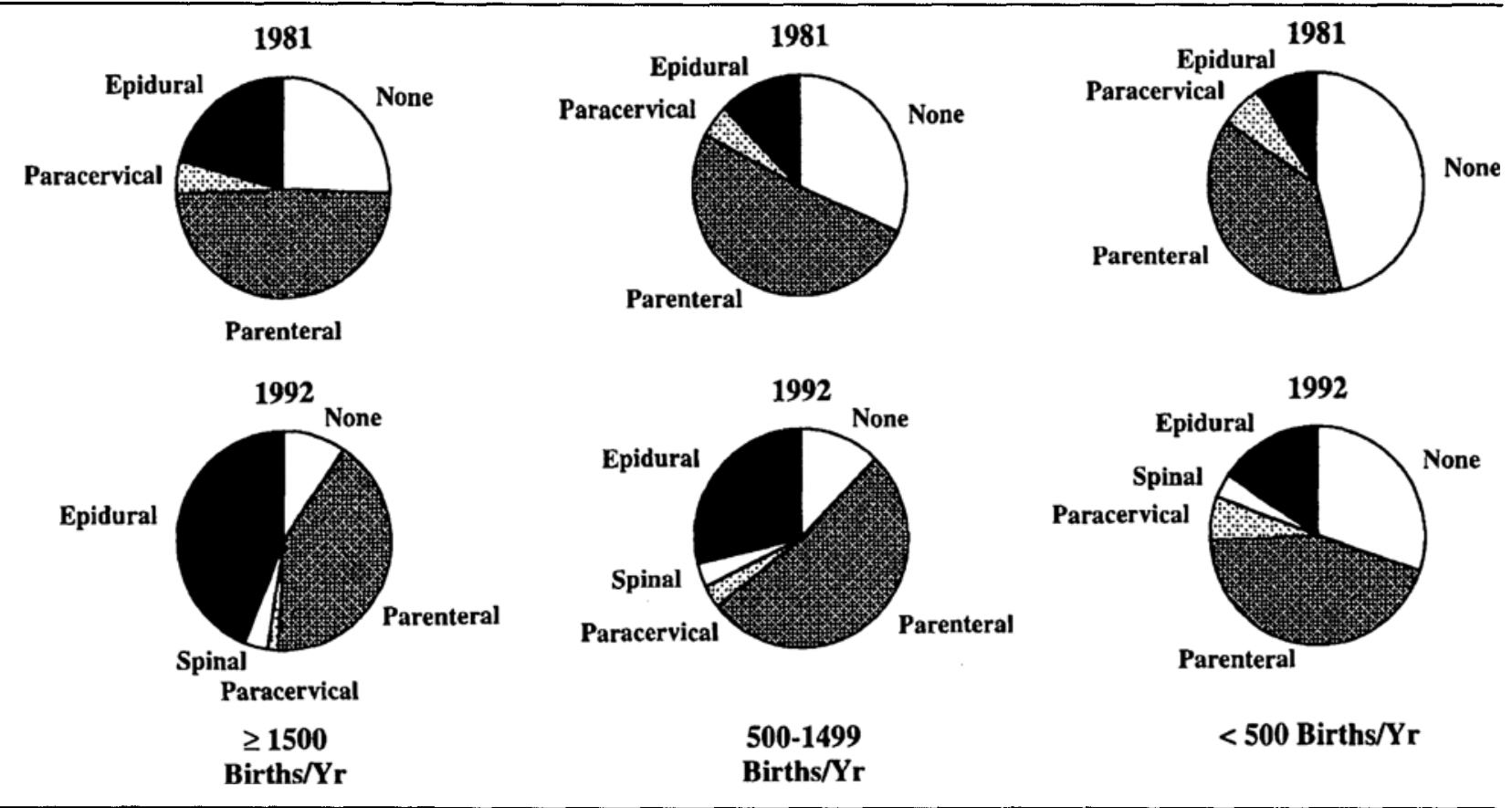

FIGURE 5 : Méthodes d'analgésie durant le travail aux Etats-Unis en 1981 (rangée du haut) et en 1992 (rangée du bas). Les colonnes sont formées à partir du nombre d'accouchements par année. Réf. 4.

$0,3 \mathrm{~g} \cdot \mathrm{ml}^{-1}$ ) semble diminuer considérablement ce risque $(5-7 \%)^{11,12}$.

L'utilisation de mélanges d'anesthésique local dilué et d'opiacés limite aussi l'effet de l'analgésie péridurale sur la durée du second stage du travail et la nécessité de forceps bas. Le fait de fournir une analgésie durant le second stage en utilisant une perfusion de bupivacaine $0,0625 \%$ avec fentanyl $0,0002 \%$ entraîne la même fréquence d'utilisation de forceps qu'une perfusion de $\operatorname{salin}^{13}$. La fait d'ajouter $10 \mathrm{~g}$ de sufentanil à un bolus de $10 \mathrm{ml}$ de bupivacaïne $0,125 \%$ avec adrénaline $1: 800,000$ diminue à la fois la quantité requise de bupivacaïne pour l'analgésie durant le travail de même que la fréquence d'accouchement avec forceps ${ }^{14}$. Cependant, jusqu'à maintenant, aucune étude n'a démontré que la concentration de l'anesthésique local utilisée est un élément contributif important à «l'effet» de l'anesthésie péridurale sur le besoin de césarienne. Au contraire, dans deux études récentes où l'on n'a pas réussi à démontrer de risque accru de césarienne associé à l'analgésie péridurale durant le travail, on utilisait des perfusions de bupivacaïne $0,125 \%$ avec fentanyl. Même si le risque de césarienne n'est pas augmenté, une perfusion prolongée de ce mélange peut causer un bloc moteur significatif chez la mère, prolonger le deuxième stage du travail, augmenter l'incidence de malprésentation et augmenter la fréquence d'utilisation de forceps ${ }^{12,15}$.

La ropivacaïne, à concentration élevée, produit moins de bloc moteur que la bupivacaïne. $\grave{A}$ basse concentra- tion, aucun des deux anesthésiques ne produit de bloc moteur significatif ${ }^{16}$. Employée seule, même la ropivacaine $0,125 \%$ produit un peu de faiblesse musculaire chez la plupart des parturientes ${ }^{17}$. Lorsqu'utilisée comme constituante d'un mélange anesthésique local dilué et d'opiacé, la ropivacaïne s'est avérée moins efficace qu'une même concentration de bupivacaïne (Tableau) ${ }^{18}$.

Jusqu'à récemment, la composition exacte de ces mélanges d'anesthésique local et d'opiacé a été établie de façon empirique. Des études récentes ont évalué de façon systématique l'interaction entre les anesthésiques locaux et les opiacés lorsqu'utilisés pour l'analgésie péridurale durant le travail. Columb et al. ont réalisé une élégante série d'études qui ont défini la concentration

TABLEAU I Bupivacaïne vs ropivacaïne pour analgésie durant le travail.

\begin{tabular}{llll}
\hline & Bupivacaine & Robivacaine & $P$ \\
\hline EVA @ 8 min & 3,0 & 0,8 & $<0,05$ \\
EVA @ 10 min & 1,6 & 0 & $<0,05$ \\
EVA @ 14 min & 0,7 & 0,0 & NS \\
Patients recevant 1 dose-bolus 60 & $<0,05$ & \\
Patientes avec bloc moteur & 0 & 0 & NS \\
\hline
\end{tabular}

Les cathéters périduraux ont été installés et vérifiés avec $45 \mathrm{mg}$ de lidocaïne et $15 \mathrm{~g}$ d'adrénaline. Par la suite, un bolus de $15 \mathrm{ml} \mathrm{de}$ solution contenant $20 \mathrm{mg}$ d'anesthésique local $(0,13 \%)$ et $10 \mathrm{~g}$ de sufentanil a été injecté. L'analgésie a été maintenue avec une perfusion à $12 \mathrm{ml} \cdot \mathrm{hr}^{-1} \mathrm{~d}^{\prime}$ une solution contenant $0,07 \%$ d'anesthésique local et $0,5 \mathrm{~g} \cdot \mathrm{ml}^{-1}$ de sufentanil. Réf. 18 . 


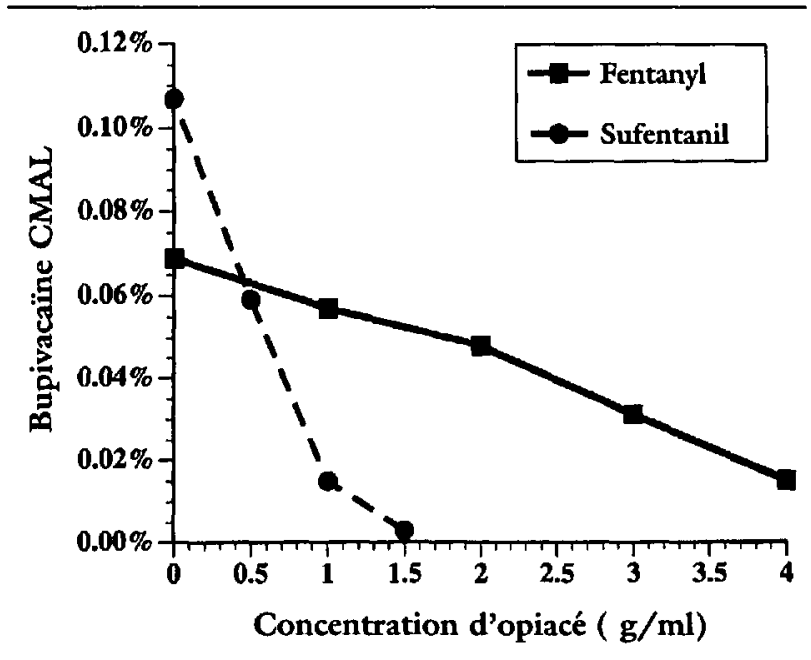

FIGURE 6 : Effet de l'augmentation des doses de fentanyl ou de sufentanil sur la concentration médiane efficace (CMAL) de bupivacaïne. Les femmes en travail recevaient une injection péridurale de $20 \mathrm{ml}$ d'un mélange de bupivacaïne et d'opiacé. Une analgésie efficace était définie par un score de $s$ ou $=$ à 10 en dedans de 30 min. Le fentanyl et le sufentanil entraînent une réduction, proportionnelle à la dose, de la CMAL de la bupivacaïne. Ref. 19, 20.

médiane efficace d'un anesthésique local (CMAL) chez des femmes en travail. La CMAL est définie comme la concentration d'un anesthésique local qui, lorsqu'administré en volume de $20 \mathrm{ml}$, produira une analgésie chez $50 \%$ de parturientes durant le premier stage du travail $^{19}$. Le fentanyl et le sufentanil diminuent tous deux la CMAL de la bupivacaïne péridurale selon un mode

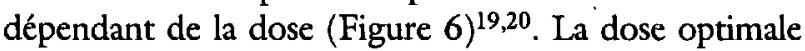
de fentanyl péridural semble être de $3 \mathrm{~g} \cdot \mathrm{ml}^{-1}$, des doses plus fortes augmentant la fréquence du prurit ${ }^{19}$.

\section{Analgésie combinée spinale-épidurale (CSE)}

L'analgésie combinée péridurale-rachidienne (CSE), utilisant des opiacés par voie sous-arachnoïdienne et une infusion péridurale d'un mélange d'anesthésique local dilué et d'opiacé, gagne rapidement de la popularité comme option pour l'analgésie durant le travail. Les avantages prouvés de cette technique incluent un début rapide ${ }^{21}$, et un taux élevé de satisfaction maternelle ${ }^{22}$. La plupart des anesthésistes utilisent la technique de l'aiguille à travers l'aiguille pour réaliser leur CSE. En dépit d'inquiétudes théoriques concernant l'injection de particules métalliques, la migration sous durale du cathéter péridural, la méningite et la céphalée post effraction duremérienne, les risques de la CSE sont comparables à ceux de l'analgésie péridurale ${ }^{23}$. Une dispersion facilitée de la médication injectée par voie péridurale est associée à l'injection sous arachnoïdienne $^{24}$. Cet effet semble en relation avec une diffusion

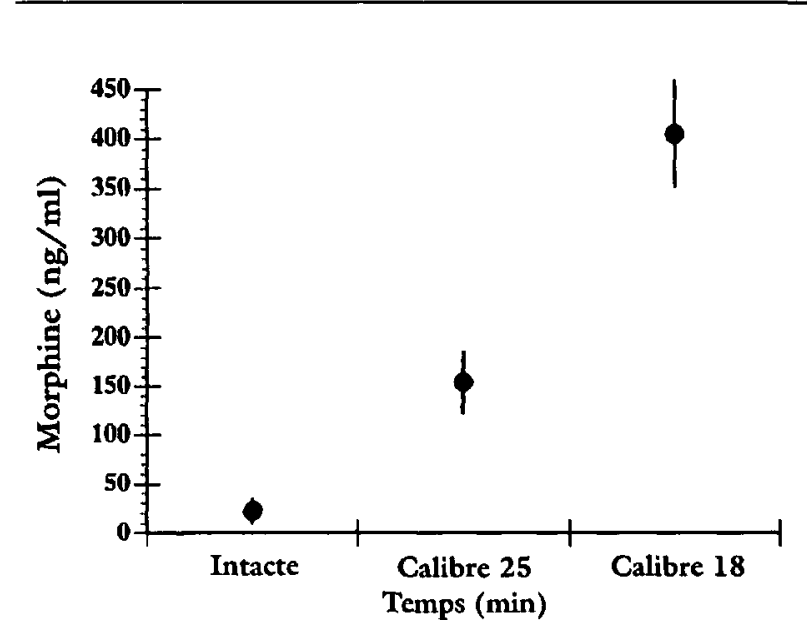

FIGURE 7 : Moyenne + ET de la concentration de morphine du LCR mesurée dans la grande citerne six heures après l'injection péridurale lombaire de $0,2 \mathrm{mg} \cdot \mathrm{kg}^{-1}$ de morphine chez le mouton. Chez quelques animaux, la dure-mère lombaire a été perforée avec une aiguille de calibre 18 ou 25 une heure avant l'injection de morphine. Réf. 25.

facilitée de la médication péridurale par le trou dans la dure-mère (Figure 7$)^{26}$. Chez des femmes en travail, la bupivacaine péridurale produit un bloc sensitif plus étendu de un ou deux dermatomes lorsqu'injectée après une ponction de la dure-mère que lorsqu'utilisée uniquement de façon péridurale ${ }^{13,24}$.

Les risques liés à l'injection sous arachnoïdienne d'opiacés sont potentiellement plus importants que les risques de la tech nique de l'aiguille à travers l'aiguille. Deux préoccupations sont particulièrement pertinentes : la dépression respiratoire et les changements du cœur fœetal.

\section{Dépression respiratoire}

Le sufentanil par voie sous arachnoïdienne a été associé à des dépressions respiratoires maternelles et des arrêts dans plusieurs circonstances. Selon les premiers rapports, cette complication est survenue chez des parturientes recevant de grosses doses $(15 \mathrm{~g})$ ou des injections répétées de la médication ${ }^{26,27}$. Par la suite, d'autres auteurs ont rapporté d'autres incidents survenant après $10 \mathrm{~g}$ de sufentanil, soit seul, soit associé à $2,5 \mathrm{mg}$ de bupivacaïne $^{28,29}$. Dans une série, le risque d'arrêt respiratoire après sufentanil intrathécal était d'approximativement $1: 5000^{29}$. L'injection intrathécale est une façon très efficace d'apporter le sufentanil au tronc cérébral ${ }^{30}$. Un $\mathrm{CO}_{2}$ de fin d'expiration élevé et une dépression de la réponse ventilatoire au $\mathrm{CO}_{2}$ se produit régulièrement ${ }^{31,32}$. Les parturientes qui ont auparavant reçu des opiacés par voie 


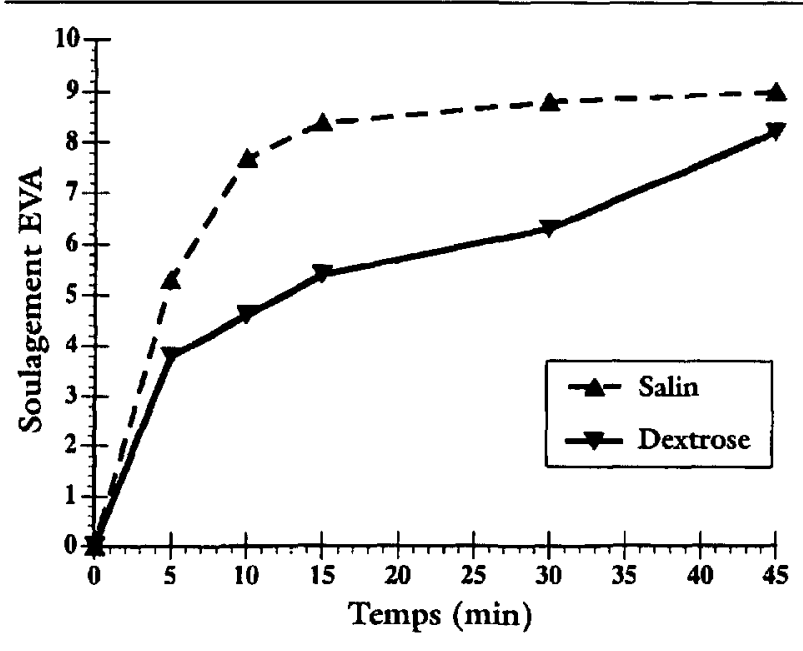

FIGURE 8 : Échelle visuelle analogue (EVA) de soulagement de la douleur chez des femmes en travail qui ont reçu une injection intrathécale de $10 \mathrm{~g}$ de sufentanil dilué dans le salin ou dans le dextrose. Le sufentanil hyperbare produit moins d'analgésie que le sufentanil isobare. Réf. 30

systémique peuvent être plus à risque face à cette complication $^{29,33}$. Toutes les parturientes qui reçoivent du sufentanil par voie intrathécale devraient être surveillées avec un saturomètre pour au moins une heure après l'injection.

\section{Changements du cour fotal}

Selon la définition retenue, la bradycardie foetale survient chez 3,9 à $23 \%$ des parturientes en travail qui reçoivent du fentanyl ou du sufentanil intrathécal ${ }^{34-36}$. Certains auteurs ont suggéré que ce problème survient plus souvent lors de l'analgésie rachidienne que lors de l'analgésie péridurale $^{34}$. Cependant, une revue de la littérature plus ancienne démontre que la bradycardie fotale survient aussi lors de l'installation de l'analgésie péridurale avec de la bupivacaïne dans 7,9 à $12,5 \%$ des cas $^{37}$. Deux études récentes n'ont pas montré de différences entre l'analgésie péridurale et l'analgésie rachidienne quant à la fréquence de bradycardie foetale $(3,9-15,4 \%)$ ou quant «aux anomalies cliniquement significatives du rythme cardiaque foetal» $(22 \%)^{35,36}$. L'hypertonie utérine a été identifiée comme cause de la bradycardie foetale après analgésie pour le travail tant péridurale que rachidienne ${ }^{35,37,38}$. Ces bradycardies rentrent habituellement dans l'ordre sans conséquence pour le fotus et sans nécessité d'intervenir chirurgicalement.

\section{Site d'action}

Certains médicaments, pg les anesthésiques locaux, ont un site d'action rachidien, clairement segmentaire, après injection intrathécale. D'autres médicaments (pg les opiacés, la néostigmine) diffusent rapidement dans le LCR pour atteindre des sites d'action tant spinaux que supraspinaux. Nous avons présumé depuis longtemps que les opiacés administrés par voie intrathécale, comme le fentanyl et le sufentanil, produisent l'analgésie du travail par leur effet spinal et qu'occasionnellement ils atteignent le tronc cérébral et produisent des effets secondaires comme les nausées, la somnolence et la dépression respiratoire. Cependant, une étude récente suggère qu'une partie de l'analgésie produite par le sufentanil intrathécal provient d'un effet sur des sites supraspinaux ${ }^{30}$. Ferouz et al. ont comparé, chez des parturientes en travail, l'efficacité et les effets secondaires du sufentanil isobare au sufentanil hyperbare. Tel que prévu, le sufentanil isobare $10 \mathrm{~g}$ a entraîné rapidement une analgésie pour le travail et du prurit. Mais le fentanyl hyperbare, que les auteurs espéraient voir produire une analgésie spinale sans effets secondaires supraspinaux, n'a produit qu'une analgésie limitée (Figure 8). Il est possible que le sufentanil hyperbare ait diffusé jusqu'à un niveau spinal thoracique bas mais non jusqu'au tronc cérébral. Ces résultats suggèrent que l'analgésie produite par le sufentanil intrathécal résulte d'effets tant au niveau spinal que supraspinal. Cette théorie s'appuie sur des études animales qui montrent du synergisme entre les opiacés spinaux et les supraspinaux $^{39}$. En clinique, cette trouvaille signifie que les effets secondaires supraspinaux, comme la dépression respiratoire, sont peut-être inséparables de l'effet analgésique des médicaments injectés par voie intrathécale.

\section{Conclusion}

Bien qu'il n'y ait pas de "nouvelles» possibilités pour soulager la douleur durant le travail, notre compréhension des tech niques couramment disponibles continue à s'améliorer. Nous sommes chanceux de pouvoir actuellement soulager la douleur du travail de façon sécuritaire. Le temps ainsi que des études en clinique et en laboratoire, menées soigneusement, vont améliorer notre connaissance des forces et des limites des approches actuellement disponibles dans l'analgésie du travail pour nous permettre d'améliorer et de raffiner les soins que nous pouvons offrir à toutes ces femmes.

\section{Références}

(Voir page RI42) 